\title{
Evaluation of Leisure Agriculture Efficiency and Development Path Innovation Under the Supply Side Horizon: Survey Data From Huangpi District
}

\author{
Yan Zhou ${ }^{1,2}$, Juan Xia ${ }^{1}$, Qi Gong ${ }^{1}$ and Zhihong Wang,** \\ ${ }^{l}$ Wuhan Academy of Agricultural Sciences, Wuhan, Hubei 430000, China \\ ${ }^{2}$ College of Economic Management, Huazhong Agricultural University, Wuhan, Hubei 430070, China \\ *Corresponding author. Email: 13476284344@126.com
}

\begin{abstract}
Taking Huangpi District of Wuhan as the research object, the paper evaluates the efficiency of leisure agriculture operation, and then innovates the development path of leisure agriculture. At last, we provide technical basis and policy guidance for the development of leisure agriculture in Huangpi District. Taking the survey data of 72 leisure agricultural management entities in Huangpi District as a sample, the index system of leisure agriculture efficiency evaluation was constructed, and the efficiency of leisure agriculture business model and the efficiency of business enterprise were evaluated by DEA model. The efficiency of leisure agriculture business model in Huangpi District was from leisure to holiday mode, popular science education mode, farmhouse music mode, sightseeing picking mode and village township mode. Among them, only leisure resort mode reached DEA. The average efficiency of comprehensive agricultural enterprise management in Huanghua District is 0.676 , the average technical efficiency is 0.771 , the average efficiency of scale is 0.884 , and the overall operating efficiency is low. Excessive investment in capital and land elements and insufficient economic and social output are the main factors restricting the operational efficiency of leisure agricultural enterprises in Huangpi District. The efficient development of leisure agriculture in Huanghua District can be promoted by determining the development model and priority order of leisure agriculture, optimizing layout, factor integration and differential management.

Keywords: Supply side reform, leisure agriculture, efficiency evaluation, development path, Huangpi District
\end{abstract}

\section{INTRODUCTION}

With the rapid improvement of living standards, the concepts of green, environmental protection and enjoyment, as well as healthy, leisure and natural lifestyle, have become the aspiration and pursuit of urban and rural residents. Leisure agriculture is a new form of business with functions of leisure, entertainment, tourism and so on. It is an adaptive adjustment to the new leisure consumption demand in urban and rural areas and effectively meets people's demand for a better life. However, the current leisure agriculture is still in the initial stage of development and exploration period, facing practical problems such as the scale of management and efficiency improvement. So it is urgent to clarify the development path of leisure agriculture, integrate and optimize the input of various elements of leisure agriculture, and achieve the dual improvement of quality and efficiency.

In recent years, on the basis of theoretical sublimation and practical investigation of leisure agriculture, many scholars and institutions have carried out beneficial exploration on the development mode, management efficiency, development strategies and other contents of leisure agriculture, providing theoretical support and experience reference for the development of leisure agriculture. With regard to the development mode of leisure agriculture, there are also differences in the results and classification effects according to different classification methods. For example, leisure agriculture can be divided into three types based on the different development subject leadership: farmer-led development mode, government-led development mode and enterprise-led development mode [1]. The classification results of this mode are helpful to clarify the government function orientation in the development of leisure agriculture. According to the different modes of operation and management, the leisure agriculture mode can be summarized into three types: the government-guided farmer management mode, the enterprise-invested farmer participation mode, and the leading enterprise-led management mode [2], which is helpful to strengthen the management of leisure agriculture. According to product differences, leisure agriculture can be divided into six modes [3]: agricultural display, agricultural participation, eco-tourism, folk culture, rural life experience, and rural vacation entertainment. This division helps to adapt to and meet the needs of the market and users. On the management efficiency of leisure agriculture, scholars have done a lot of work based on different perspectives. For example, the 
DEA model is used to evaluate the operation efficiency of leisure agriculture parks[4], the operation efficiency of leisure agriculture management entities [5], and the comprehensive efficiency of leisure agriculture development [6]. DEA and FA models are used to evaluate the efficiency of leisure agriculture in various provinces and analyze the ability of the market to continue to develop [7]. And fuzzy evaluation method and analytic hierarchy process were used to quantitatively analyze the development level and regional development potential of leisure agriculture [8-9]. Regarding the development strategy of leisure agriculture, the existing literature mainly puts forward targeted policy suggestions based on problem orientation, efficiency evaluation and factor analysis. For example, in view of the problems of low social and economic benefits, small scale and unreasonable planning and layout in the development of leisure agriculture, specific solutions are put forward based on the problem orientation[10-11]. On the basis of efficiency evaluation, to integrate and optimize the input of leisure agriculture factors or increase the output of leisure agriculture management [4-6]. Through the analysis of the factors affecting the development of leisure agriculture, scholars put forward the development strategies of leisure agriculture such as integrating factor resources, expanding consumer groups, and strengthening service innovation[12]. In addition, based on a special perspective such as the value construction, it is proposed that leisure agricultural enterprises should regard internal value as the core competitiveness of leisure agricultural enterprises[13], in order to enhance enterprise value, which is also an innovation of leisure agricultural development strategies.

To sum up, the existing literature has done a lot of research on the business mode, efficiency evaluation and development strategy of leisure agriculture, providing reliable technical basis and suggestions for formulating the development strategy of leisure agriculture and improving the development level of leisure agriculture. However, the current leisure agriculture model has not formed a unified standard of division, which directly affects the efficiency evaluation and development path choice of leisure agriculture. From the perspective of full efficiency, it is rare to make a comparative study of enterprise operating efficiency and operating mode efficiency. The government is the main body of the structural reform on the agricultural supply side, and the research on the development strategy and policy of leisure agriculture from the supply side perspective needs to be further supplemented and enriched. In this paper, DEA model is used to evaluate the efficiency of leisure agriculture management and the efficiency of management mode. On this basis, the development strategy and path of leisure agriculture are innovated from the perspective of supply side, providing necessary data support and theoretical basis for better promoting the development of leisure agriculture.

\section{DEFINITION AND MODE DIVISION OF LEISURE AGRICULTURE}

\subsection{Definition of Leisure Agriculture}

Defining the connotation of leisure agriculture is also the premise and key to evaluate the efficiency and innovate the development path of leisure agriculture. Leisure agriculture is a new form of agricultural production and management, which integrates agricultural production, tourism, business services, leisure and entertainment, scientific research, education and other functions. It has the following connotative characteristics:

(1) Based on agriculture: leisure agriculture is developed on the basis of traditional agriculture and takes agriculture as the carrier; (2) The purpose is leisure experience: the essential purpose of leisure agriculture is to provide people with leisure life experience; (3) The features are multi-functional: the key to distinguish leisure agriculture from traditional agriculture is to have not only the traditional agricultural function but also the non-economic production function of agriculture; (4) The core is industrial integration: promoting the integration of primary, secondary and tertiary industries is the key and core of leisure agriculture development; (5) The essence is a new form of agriculture: the essence of leisure agriculture is a new form of agricultural production and management, as well as an innovation of agricultural production methods.

\subsection{Classification of Leisure Agriculture Models}

According to the connotation characteristics of leisure agriculture, from the perspective of functional differences, we divide it into five modes: Agritainment, sightseeing and picking, leisure and vacation, popular science education, villages and township, etc. Agritainment mode refers to the management mode in which farmers use their courtyard, agricultural products and surrounding rural scenery and natural scenic spots to attract tourists to come for leisure and entertainment. The sightseeing and picking mode refers to taking rural landscapes, agricultural production activities and special agricultural products as tourist attractions, developing agricultural tourism, forest and fruit tourism, flower tourism, fishery tourism, animal husbandry tourism and other different themed tourism activities to meet the psychological needs of tourists to experience agriculture and return to nature. The leisure and vacation mode relies on the natural rural scenery, comfortable and pleasant climate, unique rural resources and green ecological space, and combines with the surrounding pastoral landscape and folk culture, to build some leisure and entertainment facilities for providing tourists with rest, vacation, entertainment, catering, fitness and other services. The popular science education model refers to using scientific and educational venues such as agricultural 
sightseeing parks, agricultural science and technology eco-parks, agricultural product exhibition halls, agricultural-expo parks or museums to provide tourists with tourist activities that understand agricultural history, learn agricultural techniques, and increase agricultural knowledge. The village and township model refers to using ancient village and township house buildings and the new rural pattern as tourist attractions to develop the sightseeing tourism. It can be found that the common features of different modes of leisure agriculture are all based on agriculture, integrating agricultural economic production functions and non-economic production functions to provide featured agricultural products and services. The difference is that there are obvious differences in the non-productive functional products provided to meet different consumer groups. Dividing the management mode according to the multi-function of leisure agriculture can not only implement unified protection and support by the economic production function of agriculture, but also implement differentiated management by the non-economic production function of leisure agriculture, which is helpful to formulate the development strategy and optimize the development path of leisure agriculture.

\section{CONSTRUCTION OF EVALUATION MODEL FOR LEISURE AGRICULTURE EFFICIENCY}

\subsection{Selection of Evaluation Index System}

The efficiency of leisure agriculture is a comprehensive concept, including the overall development efficiency of leisure agriculture, the operating efficiency of enterprises, and the efficiency of model operation, etc. At the macro level, leisure agriculture efficiency refers to the management efficiency of leisure agriculture industry, which is used to describe the overall development level of this new form. At the meso-level, there are obvious differences in the mode of production, products and services, and management means of different types of leisure agriculture, and the efficiency of leisure agriculture can be used to describe the efficiency of its management model. At the micro level, leisure agriculture efficiency refers to the operating efficiency of enterprises and farmers engaged in leisure agriculture production, which is used to describe the operating conditions of leisure agriculture enterprises. However, the existing evaluation system focuses on the efficiency evaluation of leisure agriculture from a single use or perspective. The scope of application is narrow, and there is a lack of a comprehensive system that can represent multiple uses and can be used for horizontal comparison between different systems, which are not conducive to the top-level design of leisure agriculture from the macro level [14]. Therefore, we plan to use the combination of the input-output index system and the comprehensive benefit index system to construct an index system which is suitable for the efficiency evaluation of leisure agriculture management mode and the efficiency evaluation of management subjects, so as to give full play to the versatility of the evaluation index system and the comparability of evaluation results. Specifically, the first-level index is determined by the input-output theory, and the production factors such as land, labor and capital are selected as the input index by the production function theory. According to the comprehensive benefit principle, economic output, social output and ecological output are selected as the output index, as detailed in Table 1. Incorporating ecological output into the evaluation system is to take into account that some enterprises over-developed land, forced conversion of land use, and engaged in non-agricultural production and management in order to increase income, resulting in land irreversibility and ecological damage.

Table 1 Evaluation Index System of Leisure Agriculture Efficiency

\begin{tabular}{|c|c|c|c|}
\hline \multirow{7}{*}{$\begin{array}{l}\text { Input-output } \\
\text { Index of } \\
\text { Leisure } \\
\text { Agriculture }\end{array}$} & First-level index & Second-level index & Third-level index \\
\hline & \multirow{3}{*}{ Input index } & Land input & Land management area \\
\hline & & Capital input & Leisure agriculture investment \\
\hline & & Labor input & $\begin{array}{c}\text { Scientific research and management } \\
\text { personnel }\end{array}$ \\
\hline & \multirow{3}{*}{ Output index } & Economic output & Annual project income \\
\hline & & Social output & Number of farmers driven \\
\hline & & Ecological output & Vegetation coverage \\
\hline
\end{tabular}

relative efficiency, uses convex analysis and linear

\subsection{Selection of Evaluation Methods}

The methods of evaluating the efficiency of leisure agriculture are widely used, such as Analytic hierarchy process (AHP), Fuzzy Comprehensive Evaluation, data Envelopment Analysis (DEA), Grey Relational degree and so on. Among them, DEA is based on the concept of programming as tools, applies mathematical programming models to calculate and compare the relative efficiency between decision-making units, and evaluates the evaluation objects [15]. This method has the advantages of comprehensiveness, objectivity and unit invariance, and it does not need to establish the production function of decision-making unit to evaluate the efficiency of multiple inputs and outputs. Moreover, through the analysis of slack 
variables, it can provide a direct way for decision-makers to improve efficiency, which is widely used in all kinds of efficiency evaluation and factor analysis. This study evaluates the efficiency of leisure agriculture based on input-output theory. Because the evaluation index system is highly adapted to data Envelopment Analysis (DEA), data Envelopment Analysis (DEA) is selected to evaluate the efficiency of leisure agriculture. Data Envelopment Analysis (DEA) includes many models, such as CCR, $\mathrm{BCC}$, cost efficiency and Malmquist index, among which CCR model can effectively realize the comprehensive efficiency of evaluation unit's technology and scale. And the evaluation units in this paper are all cross-sectional data, so it is suitable to use CCR model as a method to evaluate the efficiency of leisure agriculture.

\subsection{Research Area and Data Source}

Huangpi District is located in the north of Wuhan City, Hubei Province, with an area of $2261 \mathrm{~km} 2$, accounting for about $25 \%$ of Wuhan. It has beautiful natural scenery and strong humanistic flavor, and has been awarded the honorable titles of "China County Tourism Star", "Ecotourism demonstration Zone" and "Advanced Collective of National Tourism System" by the state authoritative departments. It is the only "National Leisure
Agriculture and Rural Tourism demonstration Zone in 2012" in Wuhan. In recent years, Huangpi District has been actively exploring the development path of leisure agriculture and rural tourism and the tourism industry has become an important pillar industry and an important industry for revitalizing agriculture and enriching the people.

This paper selects Huangpi District as the research area to explore the development path of leisure agriculture, which is of great guiding significance to meet the needs of Wuhan residents for agricultural leisure products, improve agricultural production efficiency and rural economic structure, and promote the structural reform of Wuhan's agricultural supply side. Through questionnaires and field interviews, this paper conducts research and interviews on the main management bodies and competent departments of leisure agriculture in Huangpi District, Wuhan City, to provide data support for the development path and policy measures of leisure agriculture from the perspective of supply side. A total of 72 sample data and 68 valid samples were obtained in this survey, of which model samples of agritainment, sightseeing and picking, leisure and vacation, popular science education, villages and township accounted for $26.47 \%, 35.29 \%, 20.59 \%, 10.29 \%$ and $7.35 \%$ respectively. See Table 2 for sample distribution and main data description.

Table 2 Sample Data Sheet of Leisure Agriculture

\begin{tabular}{|c|c|c|c|c|c|c|c|}
\hline $\begin{array}{c}\text { Index } \\
\text { data/business } \\
\text { model } \\
\end{array}$ & $\begin{array}{c}\text { Annual operating } \\
\text { income (ten thousand } \\
\text { yuan) }\end{array}$ & $\begin{array}{c}\text { Farmers driven } \\
\text { number } \\
\text { (people) }\end{array}$ & $\begin{array}{c}\text { Vegetation } \\
\text { coverage }(\%)\end{array}$ & $\begin{array}{l}\text { Total land } \\
\text { area (mu) }\end{array}$ & $\begin{array}{c}\text { Investment } \\
\text { scale }(10,000 \\
\text { yuan }) \\
\end{array}$ & $\begin{array}{c}\text { All } \\
\text { employees } \\
\text { (people) }\end{array}$ & $\begin{array}{l}\text { Number of } \\
\text { samples } \\
\text { (copies) }\end{array}$ \\
\hline Maximum & 5000.00 & 100.00 & 95.00 & 3500.00 & 15000.00 & 100.00 & 68 \\
\hline Minimum & 5.00 & 1.00 & 10.00 & 0.20 & 1.50 & 1.0 & 68 \\
\hline Mean & 236.09 & 14.5 & 68.00 & 355.9 & 1100.88 & 14.72 & 68 \\
\hline Agritainment & 66.87 & 5.80 & 39.17 & 221.27 & 366.33 & 6.47 & 18 \\
\hline $\begin{array}{l}\text { Sightseeing and } \\
\text { picking }\end{array}$ & 255.25 & 17.78 & 87.71 & 373.57 & 1172.00 & 14.07 & 24 \\
\hline Leisure vacation & 73.75 & 8.83 & 60.00 & 202.57 & 492.92 & 9.58 & 14 \\
\hline $\begin{array}{c}\text { Popular science } \\
\text { education }\end{array}$ & 83.43 & 25.14 & 75.00 & 288.57 & 1333.57 & 30.57 & 7 \\
\hline $\begin{array}{l}\text { Village and } \\
\text { township }\end{array}$ & 1214.67 & 35.50 & 92.00 & 1216.77 & 4696.67 & 42.67 & 5 \\
\hline
\end{tabular}

Note: The index values of the leisure agriculture business model are all sample average values. All employees refer to the formal employees of the business unit, and the farmers driven number is the number of farmers among the employees of the business unit.

\section{EFFICIENCY EVALUATION AND RESULT ANALYSIS OF LEISURE AGRICULTURE}

\subsection{Efficiency Evaluation of Leisure Agriculture Management Mode}

\subsubsection{Input-output Benefit Analysis}

From Table 2, we can see that in terms of input of factors, the village and township mode has the highest input of land, capital, labor and other factors, of which the input of land and capital is obviously greater than that of other business modes. The village and township model needs to renovate or repair centralized town houses and ancient town buildings, so there is a great demand for capital and land. The sightseeing and picking mode also has higher capital and land investment, which is much larger than the agritainment and leisure vacation modes. The main reason is that the sightseeing and picking mode in Huangpi District is relatively developed, and the tourism picking park is large in scale and has complete functions. It covers fishing, fruit picking, sightseeing, leisure and entertainment and other functions, which can meet diverse needs. In terms of benefit output, the village and township model benefits from a larger scale, and its project has higher economic benefits and ecological benefits, but there 
is not much difference from other business models in terms of promoting farmers' employment. Sightseeing and picking mode in Huangpi District is relatively mature and has high degree of centralization, with obvious economic, social and ecological benefits. And because of limited scale, scattered distribution and fierce competition, the agritainment mode has relatively low benefit output.

Selecting annual operating income as economic output index and investment scale as economic input index, this paper makes a simple analysis on the input-output benefits of different modes of leisure agriculture by calculating the difference between economic input and output and the payback period of project investment. It can be found that the input-output difference of village and township model is the largest, but the payback period of investment is the shortest. The input-output difference of agritainment mode is the smallest, and the payback period of investment is 5.48 years. The difference between input and output of popular science education model is large and the investment payback period is nearly 16 years, and the project investment is large and the benefit is low. In the survey, it is also found that there are few sample data of popular science education model, and the market potential still needs to be tapped.

Table 3 Benefit Analysis and Efficiency Evaluation Table of Leisure Agriculture Management Mode

\begin{tabular}{|c|c|c|c|c|c|c|c|c|}
\hline Type of enterprise & \begin{tabular}{|c|} 
Annual \\
operating \\
income \\
$(10000$ yuan $)$ \\
\end{tabular} & $\begin{array}{c}\text { Investment scale } \\
\text { (10000 yuan) }\end{array}$ & $\begin{array}{c}\text { Input-output } \\
\text { difference (10000 } \\
\text { yuan) }\end{array}$ & $\begin{array}{l}\text { Payback period of } \\
\text { investment (years) }\end{array}$ & $\begin{array}{l}\text { Comprehensive } \\
\text { efficiency }\end{array}$ & $\begin{array}{l}\text { Technical } \\
\text { efficiency }\end{array}$ & $\begin{array}{c}\text { Scale } \\
\text { efficiency }\end{array}$ & $\begin{array}{l}\text { Change in } \\
\text { return to scale }\end{array}$ \\
\hline Agritainment & 66.87 & 366.33 & 299.46 & 5.48 & 0.931 & 1.000 & 0.931 & $\begin{array}{c}\text { Increase } \\
\text { progressively }\end{array}$ \\
\hline $\begin{array}{l}\text { Sightseeing and } \\
\text { picking }\end{array}$ & 255.25 & 1172.00 & 916.75 & 4.59 & 0.903 & 0.915 & 0.986 & \begin{tabular}{|c|} 
Decrease \\
progressively
\end{tabular} \\
\hline Leisure vacation & 73.75 & 492.92 & 419.17 & 6.68 & 1.000 & 1.000 & 1.000 & No change \\
\hline $\begin{array}{l}\text { Popular science } \\
\text { education }\end{array}$ & 83.43 & 953.57 & 1250.14 & 15.98 & 0.983 & 1.000 & 0.983 & $\begin{array}{c}\text { Decrease } \\
\text { progressively }\end{array}$ \\
\hline $\begin{array}{l}\text { Village and } \\
\text { township }\end{array}$ & 1214.67 & 4696.67 & 3482.00 & 3.87 & 0.876 & 1.000 & 0.876 & \begin{tabular}{|c|} 
Decrease \\
progressively
\end{tabular} \\
\hline Mean & 338.79 & 1536.30 & 1273.50 & 7.32 & 0.939 & 0.983 & 0.955 & - \\
\hline
\end{tabular}

\subsubsection{Input-output Efficiency Analysis}

In order to further investigate the efficiency of leisure agriculture management mode, we use DEA model to evaluate it according to the evaluation mode of leisure agriculture efficiency. The results are shown in Table 3 .

From the perspective of comprehensive efficiency, the average comprehensive efficiency of leisure agriculture business model is 0.939, and the difference of comprehensive efficiency among enterprises of various business models is not too large. In terms of modes, only the leisure vacation mode is effective, mainly because the investment in elements of the leisure vacation management mode is relatively small. The village and township model has higher output with higher input, so the overall efficiency is relatively low. Although the investment in the popular science education model is relatively high, there are few competitors, and social, economic, and ecological output is good, which is a potential type of leisure agriculture. In terms of technical efficiency, the average technical efficiency of leisure agriculture management model is 0.983. Except for sightseeing and picking mode, other business models are effective in technology. It shows that the allocation of its own elements in different business models of leisure agriculture is reasonable. However, due to the general pursuit of complete functions and diversified products, the efficiency of resource allocation in sightseeing and picking mode is low. From the perspective of scale efficiency, the average scale efficiency of leisure agriculture management model is 0.955 . The leisure and vacation mode enterprises have reached scale effectiveness, and scale returns remain unchanged. The scale efficiency of agritainment mode is less than 1, and the scale income is increasing, which indicates that the insufficient scale of agritainment mode limits the improvement of operating efficiency. While all other types of scale efficiency values are less than 1 , and the scale returns are decreasing, which indicates that these types of enterprises have the problem of too large scale and need to reduce the scale of enterprises to improve their operating efficiency. Therefore, the result of efficiency evaluation of leisure agriculture management model shows that the development strategy of leisure agriculture in Huangpi District should give priority to the development of leisure and vacation mode, excavate and cultivate popular science education mode, integrate and expand the operation scale of agritainment mode, and promote the optimization and functional upgrade of sightseeing and picking mode products.

\subsection{Evaluation of Management Efficiency of Leisure Agricultural Enterprises}

\subsubsection{Analysis of DEA Effectiveness}

Taking the main body of leisure agriculture as the evaluation object, the leisure agriculture efficiency evaluation model is used to evaluate the operation efficiency of leisure agriculture enterprises in Huangpi 
District. It should be noted that four leisure agricultural enterprises in the sample data are excluded from the efficiency evaluation because of the comprehensiveness of business model and the complexity of business subjects, and the effective sample data is 64 copies.

From the perspective of comprehensive efficiency, the average DEA effectiveness of leisure agriculture operators is only 0.676 , and the overall operating efficiency is on the low side. But among the 64 enterprises, 16 enterprises are effective as a whole, and the number of effective enterprises accounts for $25 \%$ of the total number of enterprises in the sample, indicating that a considerable number of leisure agricultural enterprises in Huangpi District are in good condition as a whole. For enterprises with invalid DEA, the DEA efficiency value is concentrated in the range of 0.5 to 0.7 , and the efficiency value of a few enterprises is lower than 0.3 , which is also one of the reasons for the low overall operating efficiency in Huangpi District. From the perspective of technical efficiency, the average DEA effectiveness of leisure agricultural operators is 0.771 , and the overall technical efficiency is average. The technical efficiency values of most business entities are distributed around 0.5 or 1 , and the fault phenomenon is obvious. The technical efficiency of different types of enterprises shows the characteristics of scattered agglomeration, and there are obvious differences between them. This shows that there is a great difference between the ability of leisure agricultural enterprises to allocate their own resources and the ability of enterprise management. There are only 25 enterprises with effective DEA technical efficiency, and most enterprises still need to further optimize the allocation of factor resources and strengthen the training and promotion of management and operation capabilities. From the perspective of scale efficiency, the average DEA effectiveness of leisure agriculture operators is 0.884 , and the overall scale efficiency is relatively good. Among the 64 enterprises, 38 enterprises have a scale efficiency of 1, and their scale returns are unchanged, indicating that more than half of the leisure agricultural enterprises have reached scale operation. While for other enterprises with low scale efficiency, their scale returns are increasing, indicating that by expanding the scale of enterprises, these enterprises can obtain more economies of scale and improve overall productivity.

\subsubsection{Analysis of Influencing Factors of DEA Ineffectiveness}

In order to further explore the factors affecting the operating efficiency of leisure agricultural enterprises, we analyze the reasons for the ineffectiveness of DEA. In terms of investment redundancy, DEA model operation results show that 37 operating enterprises have varying degrees of land, capital and personnel investment redundancy problems, of which the capital investment redundancy is the most serious. The maximum value of capital redundancy reaches 5.83295 million yuan, and the capital investment redundancy of 13 enterprises is more than 1 million yuan. The problem of land resource input redundancy is also quite serious. The maximum value of land input redundancy is $349.977 \mathrm{mu}$, and 9 enterprises have more than $50 \mathrm{mu}$ of land input redundancy. This shows that the problem of excessive capital and land investment of leisure agricultural enterprises in this area is very serious. Therefore, in order to improve the efficiency of leisure agricultural enterprises, on the one hand, the reasonable amount of capital and land investment should be determined according to the enterprise scale, labor force and other input resources, and on the other hand, it is necessary to improve the organization and management level to improve the utilization rate of capital and land through continuous improvement of technology. Compared with capital and land, the problem of labor input redundancy is smaller, mostly distributed between 1 and 10 people.

In terms of insufficient output, 36 enterprises have the problem of the insufficient output of economic, social and ecological benefits in varying degrees. Among them, from a quantitative point of view, the number of units with insufficient social benefit output is the largest, reaching 23. Followed by economic output, with 20 units, while the number of units with insufficient ecological output is relatively small, with only 6 units. Judging from the gap from the ideal value, the economic output shortage is relatively serious, reaching 209,000 yuan, with the ideal average value of 430,900 yuan. And the output of social benefits is also obviously insufficient. The average effective value of the leisure agriculture business unit to absorb employment is 21.11 , but the actual value is only 5.67. So the personnel scale of leisure agriculture enterprises still needs to be improved. The situation of insufficient ecological benefit output is relatively light, mainly because leisure agricultural enterprises, no matter what model or type, are based on agriculture and carry out non-economic output behaviors on the basis of economic behaviors such as agricultural planting, breeding and sightseeing. The main purpose of land is to provide carriers for agricultural management and green space.

To sum up, the factors that affect the low operating efficiency of leisure agricultural enterprises are concentrated in two aspects. First, leisure agricultural enterprises invest too much capital and land factors and are not fully utilized. Second, the economic output and social output of leisure agriculture are insufficient and scale effect has not been formed.

\subsection{The development path of leisure agriculture from the perspective of supply side}

Based on the evaluation results and influencing factors of leisure agriculture management mode and enterprise management efficiency, this paper, starting from the perspective of supply-side structural reform, puts forward specific paths for leisure agriculture development from two 
aspects of leisure agriculture development strategy selection and factor integration.

(1) Actively guide and determine the development model of leisure agriculture. In the choice of leisure agriculture development strategy, we should actively guide the development of leisure agriculture towards a high-efficiency business model through policy support and planning guidance. Specifically, different modes depend on different agglomeration effects and scale effects. For example, when the scale of agritainment mode is increasing, popular science education, sightseeing and picking, villages and township modes are in a state of decreasing scale, so the decentralization of agritainment mode restricts its operating efficiency. Therefore, the government should give full play to the functions of industrial regulation and distribution, expand the scale and optimize the spatial distribution of agritainment mode, and give play to the scale effect and agglomeration effect of the agritainment mode. At the same time, we should properly control the scale of popular science education mode, sightseeing and picking mode, village and township mode, especially the function control of sightseeing picking mode, so as to clarify the function of leisure agriculture model and optimize the allocation of elements.

(2) Cultivate brand features and optimize the spatial layout of leisure agricultural enterprises. Although the market demand for leisure agriculture is large and the development prospect of leisure agriculture can be promising, the development of leisure agriculture projects still needs to coordinate the supply of leisure agriculture producers and the demand of leisure agriculture consumers, and establish a complete supply and demand industrial chain. At present, in the management mode of leisure agriculture in Huangpi District, sightseeing and picking mode and agritainment mode account for a relatively high proportion, while popular science education and village and township mode account for a relatively low proportion. The fierce competition among various management enterprises for seizing the market has resulted in low economic benefits, homogenization of products, mismatch between product supply and market demand and other problems. The competent department should reasonably arrange the development types of leisure agriculture and optimize the spatial layout of leisure agricultural enterprises according to the endowment of regional natural resources and the comparative advantage of industry. At the same time, it is also necessary to cultivate characteristic enterprises, jointly create regional leisure agriculture brand characteristics, and expand the influence of leisure agriculture brand.

(3) Vigorously promote the integration of factor resources and improve the scale of leisure agriculture economy. On the one hand, the government should, on the basis of sufficient research and demonstration, set a reasonable entry threshold for the leisure agriculture model, and guide business entities to make rational decisions in terms of investment scale, land use scale, and land use structure, etc. On the other hand, we should encourage agricultural operators, farmers, enterprises and other stakeholders to cooperate actively, integrate decentralized funds, surplus labor, entrepreneur wisdom and other essential resources, and jointly set up large-scale, economic, and modern leisure agricultural management enterprises to improve the efficiency of resource allocation.

(4) Implement differentiated management and control strategies to improve the operating efficiency of leisure agricultural enterprises. The government may consider implementing differentiated management and control measures on the basis of dynamic evaluation and detection of leisure agriculture operation modes and enterprise operation efficiency, and implementing differentiated support policies and regulatory measures for different leisure agriculture operation modes and enterprises. For example, leisure and vacation mode is more efficient and popular science education mode has greater potential. Therefore, Priority should be given to developing and supporting the development of such leisure agricultural enterprises, with supporting infrastructure and preferential policies. For leisure agricultural enterprises with high operating efficiency, support, reward, publicity and brand cultivation should be given. For leisure agricultural enterprises with low operating efficiency, the government should give them appropriate technical guidance or lead them to participate in the integration, and for those models or enterprises with saturated or even surplus markets, assistance should be given to them to voluntarily withdraw.

\section{CONCLUSION}

Based on the evaluation of leisure agriculture management mode and enterprise management efficiency in Huangpi District by DEA model, this paper puts forward the specific path of leisure agriculture development from the perspective of supply side, focusing on the strategic choice and factor integration of leisure agriculture development, which can not only provide necessary data support and theoretical basis for promoting the development of leisure agriculture in Wuhan city, but also provide reference for relevant research on leisure agriculture efficiency evaluation. The main conclusions are as follows: (1) the efficiency of leisure and vacation model in Huangpi District is the highest, while that of villages and townships is the lowest, and there are significant differences in the management efficiency of different leisure agricultural enterprises. (2) Excessive investment in capital and land elements and insufficient economic and social output are the main factors that restrict the improvement of management efficiency of leisure agricultural enterprises in Huangpi District. (3) Reasonable determination of the development model and priority of leisure agriculture, optimization of layout, integration of elements, and differentiated management and control should be the feasible paths for the development of leisure agriculture in Huangpi District. 


\section{ACKNOWLEDGMENT}

This study was supported by the National Natural Science Foundation of China (Project No. 71603288), the Innovation Project of Wuhan Academy of Agricultural Sciences (Project No. CX201908)

\section{REFERENCES}

[1] Yayu Yan, Qing Zhang. The characteristics of agricultural leisure tourism and its development model, Agricultural Economy, 2008(01): pp.24-26.

[2] Zhang Yang. Research on Chengdu's leisure agriculture business model from the perspective of business entities, Southwest University of Science and Technology, 2018.

[3] Junyi Niu. The development model and countermeasures of urban leisure agriculture, Ecological Economy, 2014, 30(01): pp. 124-127+143.

[4] Fanji Shi. Evaluation of Yangling Leisure Agriculture Development Efficiency and Research on Its Development Model Optimization, Northwest Sci-Tech University of Agriculture and Forestry, 2018.

[5] Hongrui Liu, Yan An, Xuexi Huo. Organizational model of leisure agriculture and its efficiency evaluation, Journal of Northwest A \& F University (Social Science Edition), 2015, 15(02): pp.83-89.

[6] Zheng Shi, Lin Guohua. Evaluation of the development efficiency of leisure agriculture in Fujian Province based on DEA[J]. Fujian Forum (Humanities and Social Sciences Edition), 2017(02): pp.187-193.

[7] Peng Liu. Research on China's Leisure Agriculture Efficiency Evaluation and Improvement Strategy Based on DEA, Henan Agricultural University, 2017.

[8] Hong Yuan. Analysis of Regional Development Potential of Leisure Agriculture in Hubei Province
Based on AHP and Fuzzy Evaluation, China Agricultural Resources and Regional Planning, 2018, 39(09): pp.309-314.

[9] Xueying Hu. Evaluation and driving force analysis of the development level of leisure agriculture in Shaanxi Province, China Agricultural Resources and Regional Planning, 2018, 39(10): pp.256-262.

[10] Jing Jiang, Yajun Shi. The status quo, problems and countermeasures of the development of modern urban agriculture in Beijing, Research on Agricultural Modernization, 2015, 36(02): pp.168-173.

[11] Yan Xiang, Baoxiang Qu, Yanlin Hou. The characteristics and countermeasures of the development of leisure agriculture in Beijing, China Agricultural Resources and Regionalization, 2017, 38(04): pp.214-222.

[12] Xianglin Liu, Lianyang Bai, Chenzhong Jin, etc. Research on the development status and countermeasures of leisure agricultural enterprises in Loudi, Hunan: Taking Bailu Villa in Zhongyang Village as an example, Hunan Agricultural Sciences. 2013(21): pp.105-107.

[13] Jinjing Sun, Fengjun Lu, Yan Jin, et al. Construction of business model evaluation system for eco-leisure agricultural enterprises, Modern Horticulture. 2014(2): pp. 6-9.

[14] Ying Wang, Heping Wang, Lijuan Zhang. Review of research on leisure agriculture evaluation index system, China Agricultural Resources and Regional Planning, 2017, 38(01): pp.216-221+226.

[15] Junfeng Zhang, Jie Dong. Evaluation of Land Intensive Utilization of Wuhan Urban Circle Based on "Two Oriented Society", China Population, Resources and Environment, 2012, 22(01): pp.111-116. 